\title{
DZIELO SZTUKI NA GRANICY PRZESZŁOŚCI I PRZYSZŁOŚCI. HISTORIA I PATRIOTYZM W SZTUCE NIEPROFESJONALNEJ
}

\author{
A WORK OF ART - A LINK BETWEEN THE \\ PRESENT AND THE PAST. HISTORY AND \\ PATRIOTISM IN NON-PROFESSIONAL ART
}

\begin{abstract}
In her article, the author discusses art of non-professional artists who shape the national identity in an original way. In the former professional art, the works which illustrated and uplifted history were very popular. This phenomenon is still present among folk, naive, intuitive artists, generally speaking - non-professionals. The work of their hands and imagination is a tool serving the purpose of national values and ideas, and is sometimes the basis for broader considerations on the human condition. They balance between historical facts and ahistorical generalities. The martyrdom of the Polish nation with emphasis on the events of WWII has been inspiring artists, stimulating their imagination and artistic creation. Therefore numerous 'monuments of patriotic art' can be found in the wood sculpture, ceramics, painting, and glass painting works from the art collection of the Torun Maria Znamierowska-Prüfferowa Ethnographic Museum.
\end{abstract}

Key words: Polish history; outsider art; professional painters; folk art; primitivism
ALEKSANDRA WERONIKA JARYSZ

Muzeum Etnograficzne im. Marii Znamierowskiej-Prüfferowej, Toruń E-mail: sztuka@etnomuzeum.pl This work was supported by the author's own resources. No competing interests have been declared.

This is an Open Access article distributed under the terms of the Creative Commons Attribution 3.0 PL License (creativecommons.org/licenses/by/3.0/pl/), which permits redistribution, commercial and non-commercial, provided that the article is properly cited. () The Author(s) 2015.

Publisher: Institute of Slavic Studies, Polish Academy of Sciences [Wydawca: Instytut Slawistyki PAN] 
W swoim artykule autorka prezentuje sztukę twórców nieprofesjonalnych, którzy w sposób oryginalny kształtują tożsamość narodową. W dawnej sztuce profesjonalnej dzieła, które ilustrowały i uwznioślały historię były bardzo popularne. To zjawisko jest nadal aktualne wśród twórców ludowych, naiwnych, intuicyjnych, ogólnie nazywając - nieprofesjonalnych. Dzieło ich rąk i wyobraźni jest narzędziem w służbie wartości i idei narodowych, a niekiedy stanowi podstawę do szerszych rozważań nad kondycją człowieka. Balansują oni między konkretem historycznym a ahistoryczną ogólnością. Martyrologia narodu polskiego z naciskiem na wydarzenia II wojny światowej inspirowała i inspiruje twórców, pobudza ich wyobraźnię i zmusza do twórczej kreacji. Stąd też zarówno w rzeźbie w drewnie, w ceramice, na obrazach, w malarstwie na szkle, w zbiorach sztuki toruńskiego Muzeum Etnograficznego im. Marii Znamierowskiej-Prűfferowej możemy odnaleźć bogatą reprezentacje „pomników sztuki patriotyzmu".

Stowa kluczowe: sztuka nieprofesjonalna; tożsamość narodowa; sztuka ludowa; patriotyzm

Dzieło sztuki wytycza zarówno kierunek ku przyszłości jak i przeszłości, bo historia jest zawsze przypadkowa a sens nadajemy jej a posteriori.

Bourriaud, 2011, s. 27

\section{HISTORIA I SZTUKA}

Z estawiając ze sobą pojęcia sztuka i historia, łączymy dwa porządki metodologiczne, sfery odrębnych interesów i metod. Sztuka ukazuje osobiste problemy artystów, którzy jako „badacze” sfery duchowej nie muszą z góry definiować konkretnych celów swoich badań. Balansują oni na granicy sfery sacrum i profanum, korzystając z danego im przywileju - wolności wypowiedzi artystycznej. Wytwory ich pracy charakteryzują się subiektywnością. Indywidualna forma wyrazu, którą się posługują, oryginalna stylistyka oraz siła przekazu kształtuje ich wizerunek artystyczny. Historia zaś buduje konstrukcje, z którymi mogą się identyfikować miliony ludzi, a ponadto odwołuje się do obiektywizmu². Za sztuką stoi człowiek, który jest jej najważniejszym przekazem. W historii ludzie pojawiają się jedynie jako operatorzy działań. Ich osobowość jest ważna o tyle, o ile wyjaśnia podjęcie decyzji. W sztuce osobowość artysty, jego niepowtarzalność, niepokoje, kontrowersyjność, fascynacje i bezkompromisowość, jego punkt widzenia - to najważniejsze wartości.

W swoim artykule chciałabym, aby dwa porządki klasyfikacyjne: historii i sztuki zostały „połączone" poprzez wspólne ogniwo, jakim są dla mnie wybrane dzieła artystów nieprofesjonalnych³, którzy podejmowali problematykę historyczną. Przeglądając zbiory w Dziale<smiles>[3H][AlH2]</smiles>

Przykładem może być tutaj pomalowanie przez Davida Cernego na kolor różowy praskiego pomnika - czołgu symbolizującego wolność (Bernatowicz, 2009, ss. 22-24).

2 Patrz: "Nie ma historii bez świadomości granicy między królestwem rzeczywistości a tym, gdzie pełnię władzy sprawuje fikcja" (Pomian, 2006, s. 11).

3 Ze względu na złożoną problematyke terminologii służącej do określania zjawisk w sztuce powstających poza kręgiem sztuki profesjonalnej dookreślę, co rozumiem pod pojęciem twórczości nieprofesjonalnej. Jest to zjawisko na tyle zróżnicowane, że wydaje się być jednocześnie najbardziej pojemnym określeniem 
Sztuki i Estetyki Muzeum Etnograficznego im. Marii Znamierowskiej-Prüfferowej w Toruniu, nasuwa się stwierdzenie, że tematyka historyczna jawi się jako obszar niezwykłej aktywności twórców podejmujących tematy historyczne. To jednocześnie sfera niezwykle różnorodna, jeśli pod uwagę weźmiemy sposób prezentacji tego typu zagadnień. Możemy bowiem odnaleźć tu zarówno malarstwo, jak i rzeźbę, które z pietyzmem ilustrują dzieje narodu, są hołdem dla ofiar i bohaterów. Możemy zapoznać się z pracami, które stanowią komentarz do przeszłości skierowany do nas - ludzi współczesnych. Ich autorzy operują symbolami religijnymi, narodowymi, często kierując się intuicją, wrażliwością, a nie konkretną wiedzą historyczną. Dzieła te są wyrazem uczuć patriotycznych i służą ich podsycaniu. Istotnym aspektem sztuki nieprofesjonalnej jest kult historii narodowej i chęć „zamknięcia” jej w pomnikach sztuki. Chciałabym zaprezentować sztukę twórców nieprofesjonalnych, którzy w sposób oryginalny kształtują tożsamość narodową. Wytwór ich rąk jest narzędziem w służbie wartości narodowych, a niekiedy stanowi podstawę do szerszych rozważań nad kondycją człowieka. Oscylują oni między konkretem historycznym a ahistoryczną ogólnością. Na podstawie zbiorów z kolekcji sztuki toruńskiego Muzeum Etnograficznego przedstawię, w jaki sposób sztuka "rozprawia się" z pamięcią historyczną. Przy wyborze przykładowych obiektów kluczem były dla mnie odwołania do dzieł współczesnych artystówprofesjonalnych .

\section{INSPIRACJE}

W dawnej sztuce profesjonalnej, począwszy od starożytności przez średniowiecze, barok, klasycyzm i romantyzm, dzieła, które ilustrowały i uwznioślały historię były bardzo popularne. To zjawisko jest nadal aktualne czy może kontynuowane wśród twórców ludowych, naiwnych, intuicyjnych, ogólnie nazywając - nieprofesjonalnych. W dziełach zaś wspótczesnych, profesjonalnych z nurtu sztuki krytycznej, mamy do czynienia ze zdecydowanym zaangażowaniem światopoglądowym artysty.

Te dzieła nie są ilustracjami historii tylko, są jej krytyką lub przetworzeniem. Twórcy przeprowadzają wiele operacji artystycznych na historii. Najważniejsze z nich to: przenikanie historii, jej naprawianie oraz wykorzystanie jej symboli. Tym operacjom towarzyszy zróżnicowany poziom powagi od patosu do ironii (Potocka, 2011, s. 191).

W latach 50. i 60. XX wieku w twórczości artystów nieprofesjonalnych przeważały tematy związane z II wojną światową ${ }^{4}$. Można powiedzieć, że tematyka historyczna miała rangę ogólnonarodową i wyzwalała jej autorów z etykiety „artysty regionalnego". Tematy wojenne, które podejmowali twórcy starszego pokolenia ${ }^{5}$, inspirowane były w dużej mierze osobistymi doświadczeniami. Siła ich przekazu i wspomnień przekładała się na-

-.....

sfery sztuki powstającej poza akademickim obiegiem. Pod tym pojęciem można wskazać zarówno artystów określanych przez różne środowiska badaczy tego zjawiska jako naiwnych, pseudoludowych, amatorów, outsiderów, art brutowców, intuicyjnych, samorodnych, prymitywnych itp. Ich wspólną cechą jest brak wykształcenia plastycznego, niezwykły talent, wyjątkowa wrażliwość. Artyści nieprofesjonalni pochodzą z różnych środowisk społecznych i kręgów kulturowych. Kontekst biograficzny jest niezbędnym kluczem do poznania ich dziet.

4 Prezentacje w sztuce ludowej dotyczące II wojny światowej pojawiają się zarówno w malarstwie, grafice, na obrazach na szkle, jak i w rzeźbie w drewnie i ceramicznej, na dywanach dwuosnowowych oraz w wycinankach.

5 Można tutaj wymienić takie nazwiska, jak: Anna Binkuńska, Kazimierz Bułdo, Antoni Chynek, Józef Firmanty, Jan Kosiarz, Wincenty Krajewski, Adam Pawlik, Władystaw Suchojad, Roman Śledź, Jan Wojtarowicz, Tadeusz Żak, Stanisław Żywolewski. 
stępnie na twórczość młodszego pokolenia. Plastyczne manifestacje artystów nieprofesjonalnych uwalniały ich niejako z hermetycznej grupy artystów amatorów, którzy głęboko tkwią w prezentacjach kultury wiejskiej. Wartości religijne, moralne przesłania i fakty, obyczajowość i wierzenia plus realna sytuacja w kraju tworzyła na tylne spójny obraz, iż twórczość historyczna artystów nieprofesjonalnych nabierała cech uniwersalizmu6. Ekspansywność tej tematyki była również zdeterminowana działalnością instytucji kulturalnych (organizacja wystaw i konkursów), społecznych, stowarzyszeń oraz kolekcjonerów. Tematyka wojenna w sztuce nieprofesjonalnej to w dużej mierze konsekwencja prób naśladowania sztuki akademickiej oraz dążenia do uczestnictwa w kulturze narodowej (Pokropek, 2009, ss. 9-12).

\section{KOMIKS}

Współcześni artyści profesjonalni, którzy w swej twórczości podejmują zagadnienie patriotyzmu, mają duże trudności w ominięciu publicznego, upolitycznionego dyskursu na ten temat ${ }^{7}$. Pewnym rozwiązaniem jest dla nich poszukiwanie takiego nośnika treści, który nie jest zawłaszczony przez typowe "pomniki” pamięci. Mam tu na myśli chociażby prężnie rozwijającą się formułę komiksu historycznego. We współczesnej debacie o patriotyzmie taki środek wyrazu wydaje się współgrać ze specyfiką odbioru treści w kulturze popularnej. Obrazy na kanwie dobrego scenariusza to lekki, nieobarczony ciężarem oprawy kwestii narodowej sposób opowiedzenia tematów „trudnych”. Przykładem popularnych publikacji utrzymanych w konwencji komiksu są takie tytuły, jak: 1956 - Poznański Czerwiec (Jasiński, Michalski, Tkaczyk, \& Żwikiewicz, 2006), 1981. Kopalnia Wujek (Jasiński, Michalski, \& Janicki, 2006), 44. Antologia komiksu o Powstaniu Warszawskim (2007) $)^{8}$.

Pisząc na temat kondycji sztuki współczesnej w obliczu kwestii poważnych, istotnych, trudnych i zawiłych, chcę przygotować grunt pod prezentację twórczości artysty ludowego, malarza i rzeźbiarza Franciszka Lenarta (1919-1997) z Gwoźnicy Dolnej, w województwie podkarpackim. Chcę pokazać, co nieznający nurtów i zjawisk w sztuce współczesnej artysta ma wspólnego z komiksem. Mimo iż talent tego artysty najokazalej przejawia się w rzeźbie, ja chciałabym wspomnieć o cyklu jego akwarel i rysunków, którego tematem przewodnim są wydarzenia II wojny światowej. Cykl jego prac zatytułowany Historia Polski w latach 1939-45 to utrzymany w formule komiksu, humorystyczno-groteskowy obraz najważniejszych wydarzeń związanych z agresją niemiecką i radziecką na Polskę. Główni bohaterowie tych powstałych w latach 70. XX wieku obrazków to figury Stalina i Hitlera, których skomplikowane relacje ukazane są w sposób schematyczny, operujący podstawowymi symbolami. Są one w swej formule dość oszczędne, pozbawione dekoracyjno-

\section{-......}

6

Należy zaznaczyć, że w okresie PRL, przez wzgląd na cenzurę ze strony władz, tematyka historyczna niejednokrotnie ograniczała się do przedstawień Ludowego Wojska Polskiego, Batalionów Chłopskich, przyjaźni polsko-radzieckiej.

7 Sztuka krytyczna z jednej strony może być równorzędnym partnerem dla historyka. Jej alternatywna wizja historii obala jednak mity i burzy ustalony porządek dziejów. Kontrowersje, które wywołują tego typu dzieła sztuki przysłaniają często jej wartości oraz przesłanie. W tym prądzie artystycznym wartość dzieła sztuki jako przedmiotu ustępuje miejsca kreatywności myślenia. Detronizuje zwyciężonych i staje po stronie wykluczonych (patrz Domańska, 2011, ss. 75-85).

8 Innym przykładem formy ekspresji artystycznej, która równie chętnie jak współcześni twórcy komiksu czerpie inspirację z przeszłości, są murale. Te monumentalne malowidła ścienne są narzędziem sztuki zaangażowanej. Komponują się one z miejską przestrzenią, komentując ważne wydarzenia z przeszłości lub bieżące. 
ści. Dzięki temu uwypukla się ich podstawowy walor - precyzja wypowiedzi. Jego obrazy są pośrednikiem w spojrzeniu ku przeszłości. Przedstawienia historyczne Franciszka Lenarta, są klarownym nośnikiem dla wiedzy historycznej autora. Współcześni twórcy komiksu historycznego dążą właśnie do takiej prostej formy wyrazu, którą Franciszek Lenart posługiwał się w sposób intuicyjny, współgrający z jego wrażliwością, wiedzą i umiejętnościami. Aby ośmieszyć i poniżyć postać niemieckiego uzurpatora, na rysunkach Lenarta Hitler występuje zawsze w bieliźnie. Stalin, mimo iż pokazany w kompletnym stroju, swoją zadziorną postawą budzi raczej śmiech niż przerażenie. Autor w sposób konsekwentny ukrywa przed widzem dramatyzm wojennej pożogi. "Komiks" Lenarta powstał wiele lat po wojnie. Pozbawiony jest on dramatycznej ekspresji. Ta oszczędna formuła ma jednak na celu swoiste zmierzenie się z pamięcią. Poprzez ośmieszenie figur agresorów artysta stara się, aby w ten sposób zostali oni zbezczeszczeni. Nie mógł ich ukazać w dumnych pozach, przerażających scenach, ponieważ nie zasłużyli na uwypuklanie ich wielkości. Ich autokreacja, pomniki, które budowali dla potomnych poprzez swoje czyny, zostały w wizji artystycznej Lenarta uproszczone do karykaturalnych postaci. To malarskie wyobrażenie to jest według Franciszka Lenarta sprawiedliwość dziejowa.
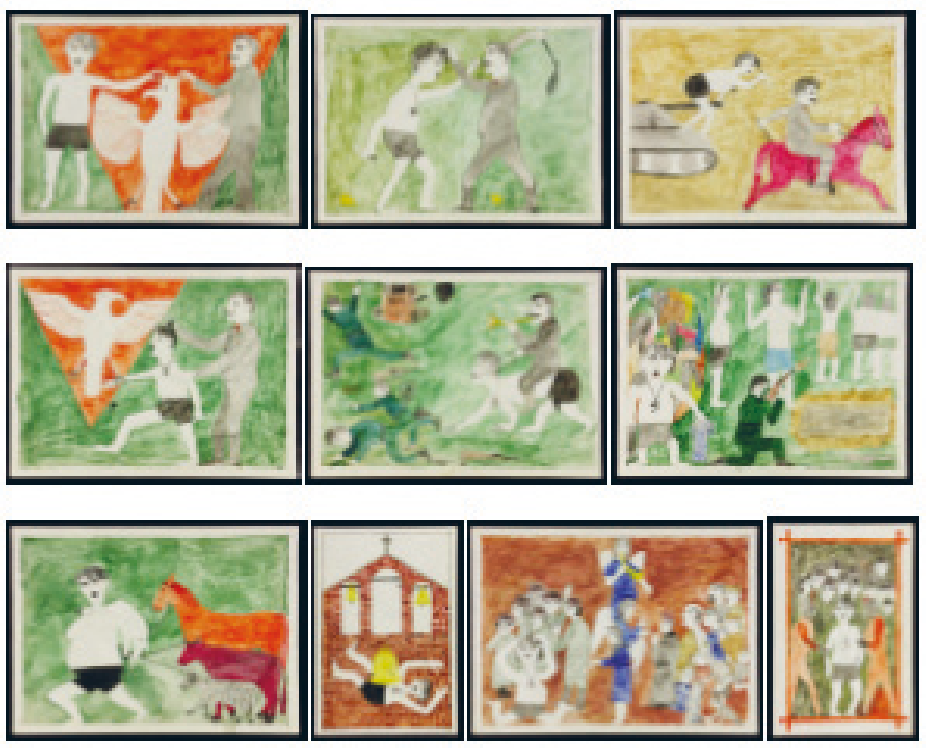

Ryc. II. 1-10 Historia Polski w latach 1939-45, Franciszek Lenart, 1979 r., akwarela, fot. Marian Kosicki, MET

\section{"SUPERBOHATER"}

Wystawa "Nowa Sztuka Narodowa” w Muzeum Sztuki Nowoczesnej, w Warszawie (kuratorzy: Sebastian Cichocki, Łukasz Ronduda, Warszawa 2012) w zamierzeniu jej twórców miała odwoływać się do marginalizowanych w dyskursie nowoczesności uczuć patriotyzmu i poczucia narodowej wspólnoty. Ta ekspozycja była również początkiem projektu badawczego Muzeum Sztuki Nowoczesnej w Warszawie, który koncentrował się na wątkach narodowych i patriotycznych we współczesnej kulturze wizualnej. Wśród 
prezentowanych prac moją uwagę przyciągnął okazałych rozmiarów wydruk cyfrowy z komiksowym "superbohaterem" - Białym Orłem. Ta postać, stworzona przez Macieja (scenariusz) i Adama (rysunki) Kmiołków, to silnie stypizowana męska figura wykreowana na wzór ikon pop kultury - Supermana, Batmana, He-Mana. Biały Orzeł zmaga się w komiksie z niebezpieczeństwami, które zagrażają naszemu krajowi. Jego biało-czerwony strój, majestatyczna postać złożona w 90\% z muskulatury, niczym spiżowy pomnik, w swojej pozie jest buńczuczna, groźna. Ten przerysowany wizerunek herosa skłania do refleksji: Czy to jest polski bohater XXI wieku? Jak dalece odbiega on od kruchych postaci bohaterów, których czyny i często męczeńska śmierć inspirowały twórców nieprofesjonalnych do oddawania im hołdu, poprzez „wskrzeszanie” ich wizerunków w drewnie, kamieniu, realizacjach malarskich. Tu szczególnie wyraziście przychodzi do mnie obraz męczennika, ojca Maksymiliana Marii Kolbego. Postać franciszkanina, w rękach i świadomości twórców nieprofesjonalnych, wykreowana została w pozie pokornego sługi Bożego. Ta nobilitacja to swoisty hołd oddany temu wyjątkowemu człowiekowi. Charakterystyczna postać w oświęcimskich pasiakach występuje m.in. na linorytach Franciszka Kurzei, w rzeźbiarskiej twórczości Antoniego Barana, Józefa Chełmowskiego, Jarosława Furgały, Jana Krajewskiego, Jakuba Królczyka, Andrzeja Wojtczaka, Piotra Wolińskiego i wielu innych. Najczęstsze przedstawienia ukazują zakonnika w celi śmierci, są także kompozycje z koronacją koroną męczeńską. W dorobku wielu artystów drugim pod względem popularności bohaterem, męczennikiem obozów koncentracyjnych prezentowanym w sztuce ludowej, był Janusz Korczak. Zamordowany w Treblince lekarz, pedagog i pisarz znalazł zaszczytne miejsce w dorobku Jarosława Furgały, Wojciecha Sadowskiego, Wacława Zielińskiego.

Wizerunki ojca Maksymiliana Marii Kolbego, w kreacjach artystycznych ukazujących jego pokore i bohaterstwo, zdecydowanie nie przystają do siły, tężyzny i witalności polskiego nowego "superbohatera". Jednak siła wyrazu ich drobnych, skromnych i delikatnych postaci zastygłych w męczeńskich pozach dociera do pokładów wrażliwości każdego z nas. Dzieło życia stanowi o ich wielkości w naszych oczach. Stąd też w sztuce nieprofesjonalnej pamięć o ich poświęceniu i dobroci sprowadza się do prezentacji kruchości ciała, bez zbędnej ornamentyki i dodatkowych rekwizytów.

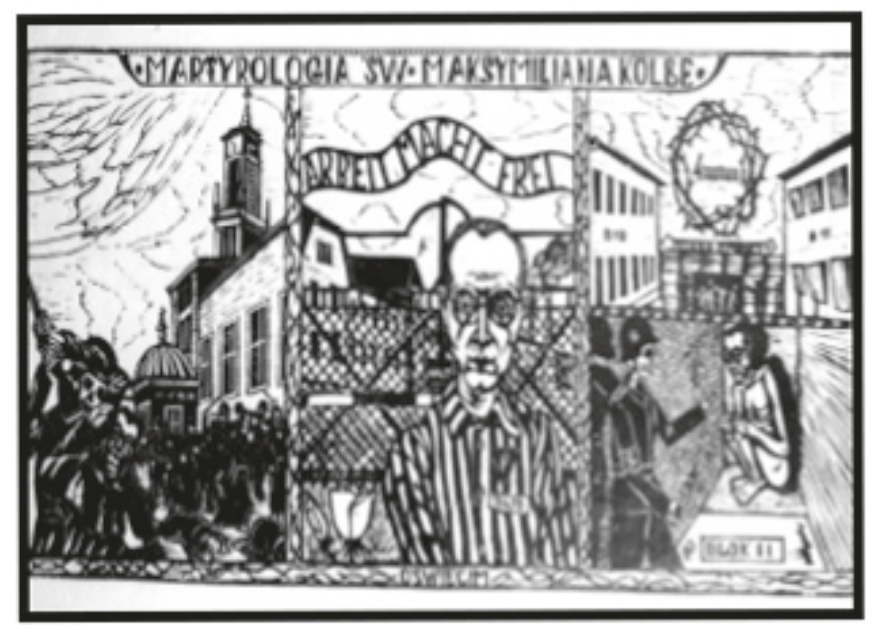

Ryc. 11. Martyrologia ks. M. Kolbe, Franciszek Kurzeja, 1985 r., linoryt, fot. Marian Kosicki, MET 
Poszukując w kolekcji sztuki toruńskiego muzeum „superbohatera”, charyzmatycznego kolosa, który z miną pełną determinacji i powagi ratuje naszą Ojczyznę, odnajduję również i taką postać. Charakterystyczna fizjonomia Lecha Wałęsy, pod koniec lat 80. XX wieku zainspirowała wielu twórców nieprofesjonalnych do utrwalenia jego wizerunku. Tworzyli oni swoiste pomniki, chcąc $w$ ten sposób złożyć hołd bohaterowi narodowemu. Jako bojownik o upragnioną wolność stał się on "superbohaterem”. Lech Wałęsa pojawia się na linorytach Franciszka Kurzei - malarza, grafika, rzeźbiarza, autora wycinanek artystycznych. Mogę wymienić tu pracę zatytułowaną "Nie ma wolności bez Solidarności” z 1989 roku, na której zamyślony wódz narodu Lech Wałęsa, w heroicznej pozie dominuje nad tłumem. Sam artysta, pracujący w Kopalni Węgla Kamiennego "Wujek”, aktywnie działał w "Solidarności" (Pyka, 2008). Ten wyjątkowo bliski jego sercu temat przełożył się na bogaty cykl prac poświęcony działalności tej organizacji, będącej dla autora synonimem wolności. Franciszek Kurzeja, żarliwy patriota, swoje zaangażowanie w Komitecie Pomordowanych Górników Kopalni "Wujek” przypłacił chorobą serca i kalectwem. W wyniku choroby i związanych z nią ograniczeń, polem walki i miejscem wyrazu jego uczuć stała się sztuka. Poprzez swoją twórczość chronił istotne dla Ślązaków wartości: religię, rodzinę, tradycję i patriotyzm. Szczególnie ten ostatni pielęgnowany był przez niego pieczołowicie i stał się znaczącym wyróżnikiem jego twórczości artystycznej. Warto wspomnieć, że urodził się on w rodzinie rdzennie śląskiej, patriotycznej, związanej w przeszłości z Wojciechem Korfantym. Prawość, uczciwość i odwaga w walce o słuszne sprawy ukierunkowały życie Franciszka Kurzei. Artystę inspirowała zarówno historia, tradycja jak i dzieje najnowsze Śląska - szczególnie powstanie "Solidarności” i przełom ustrojowy (Gajdziszewska, 2008).

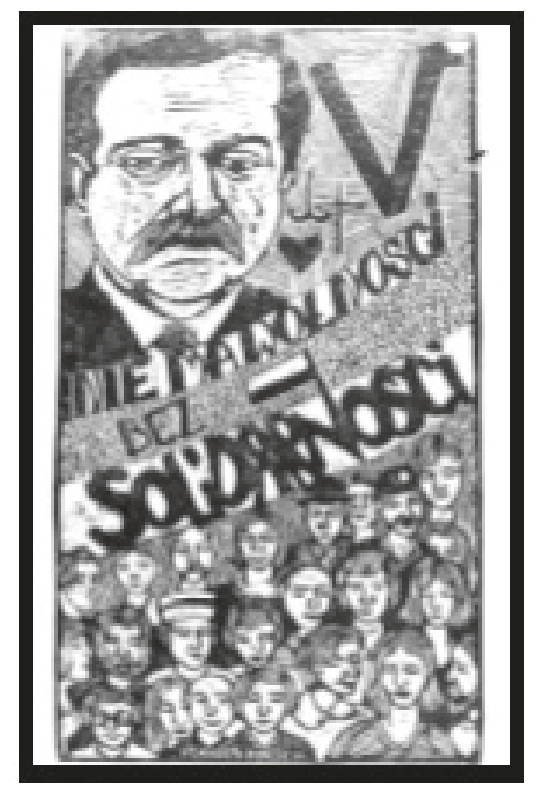

Ryc. 12. Nie ma wolności bez Solidarności, Franciszek Kurzeja, 1989 r., linoryt, fot. Marian Kosicki, MET 
Subtelna analiza doświadczenia indywidualnego, jak i silna przynależność i poczucie odpowiedzialność zbiorowej stanowią o istocie postawy moralnej artysty. Nie buduje on na nowo historii, a jedynie reinterpretuje i poszerza jej fragmenty. Jego kreacja artystyczna opiera się na wrażliwości, indywidualnym doświadczeniu i nie porywa się on na tworzenie wizji historycznej. Ma bowiem wobec historii inne powinności - upamiętniać i oddawać hołd bohaterom. „Śmierć 9 górników na Wujku 1981” z 1991 roku, to grafika o dużym poziomie szczegółowości. Operująca konkretem i przesycona informacjami, łączy rzetelną wiedzę z symboliką religijną - wizerunek płaczącej nad losem górników Matki Boskiej, z niezwykłymi umiejętnościami warsztatowymi artysty. Matka Boska Częstochowska jako opiekunka Solidarności i Królowa Polski występuje również w pracy zatytułowanej "Solidarność" z 1989 roku. Jako orędowniczka walki o wolność jest tarczą dla wojowników, wspomożeniem dla ciemiężonego narodu. Pozostając w tematyce solidarnościowej, można jeszcze wymienić karykaturalną grafikę zatytułowaną "Trójca” z 1983 roku. Widnieją na niej portrety gen. Wojciecha Jaruzelskiego z motywem sierpa, młota i pięcioramiennej gwiazdy i napisem "Siepacz", głowa Jerzego Urbana z karykaturalnie powiększonymi uszami, przypominającymi nietoperza, i podpisem „Kanalia”, oraz głowa Albina Siwaka z rogami i podpisem "Superstar”. W pracy „Zamordowani za Solidarność" z 1989 roku autor na murze wśród cierni umiejscawia 9 tabliczek z nazwiskami oraz wiekiem górników zamordowanych w walce o wolności. Tym bohaterom autor ustawia symboliczny krzyż i w precyzyjnej wymowie dzieła mówi dokładnie - „Pamiętamy”. Hasło: „polegli za wiare, wolność i godność", widnieje na grafice zatytułowanej „W hołdzie poległym” z 1989 roku. W pracy tej dominuje postać św. Barbary, u stóp której leży 9 kasków górniczych, a z nich wyrastają róże. Motyw Matki Boskiej nieodłącznie powiązanej z ludzkim cierpieniem został przez artystę wyraźnie wyeksponowany w pracy „Śląska Pieta” z 1981 roku.

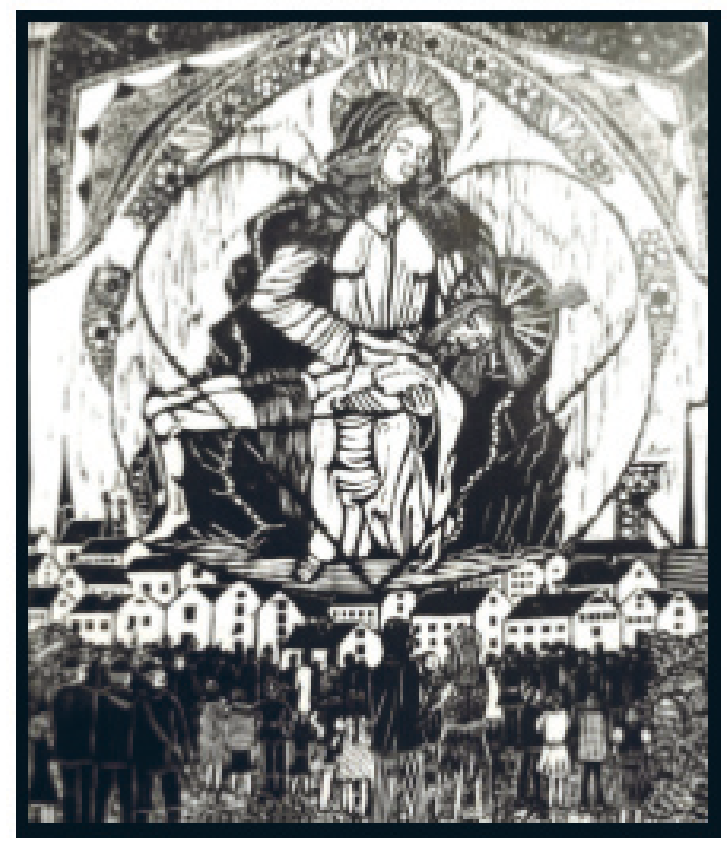

Ryc. 13. Śląska Pieta, Franciszek Kurzeja, 1981 r., linoryt, fot. Marian Kosicki, MET 
W twórczości Franciszka Kurzei duże znaczenie ma odwoływanie się do sfery sacrum. Tematy religijne $w$ jego pracach harmonizują z zagadnieniami tradycji i dziejami Ojczyzny. Jego patriotyczna postawa, która ma swoje odzwierciedlenie w sztuce, w okresie PRL była dla niego formą sprzeciwu przeciw fałszowaniu historii Śląska i manipulacjom politycznym w komunistycznym ustroju. Postawa życiowa i ekspresja artystyczna oscylująca wokół wartości i zasad uczyniła z niego herosa, który oddawał hołd bohaterom narodowym i uparcie stał na straży prawdy. Patriotyczna twórczość Kurzei stanowi ideowe posłannictwo w służbie małej ojczyzny Śląska - cykl linorytów związanych z wydarzeniami w Kopalni Wujek w 1981 roku. A także w stosunku do Ojczyzny - Polski, na przykład prace podejmujące temat zbrodni katyńskiej.

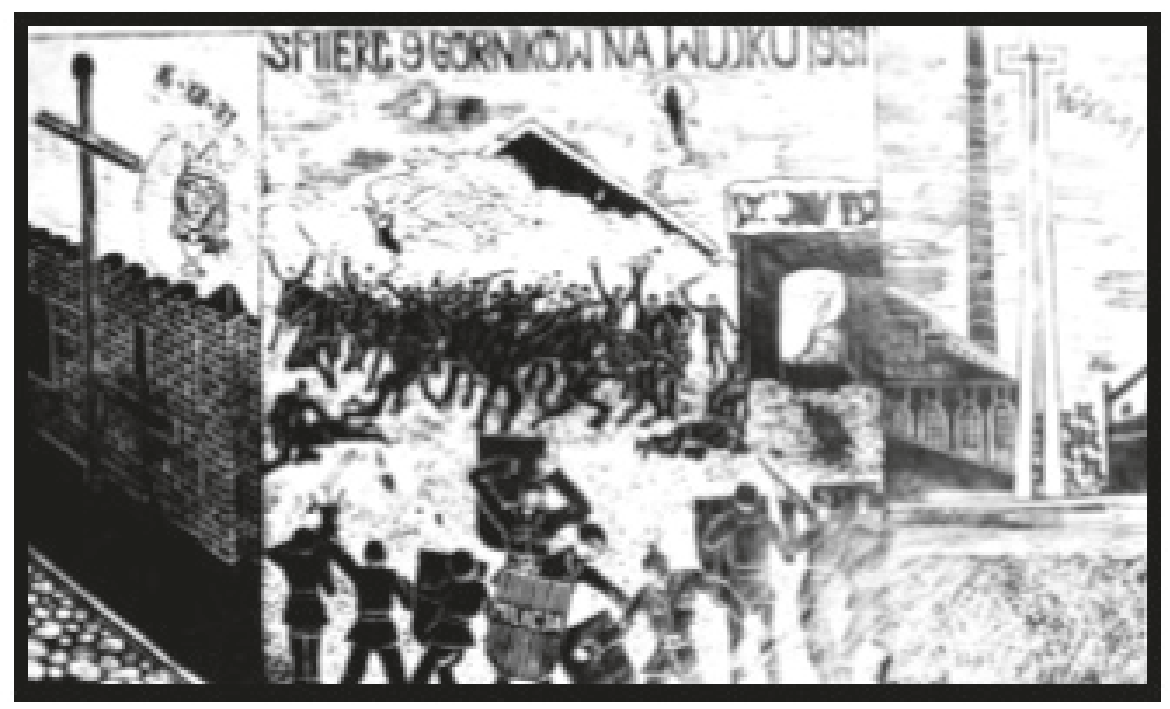

Ryc. 14. Śmierć 9 górników na Wujku 1981, Franciszek Kurzeja, 1981 r., linoryt, fot. Marian Kosicki, MET

PAPIEZ்

W Muzeum Sztuki Współczesnej MOCAK w Krakowie w czerwcu 2014 roku została otwarta wystawa „Papieże”. Ekspozycja w założeniu kuratorki Katarzyny Wincenciak miała być analizą zjawiska fascynacji Janem Pawłem II, jego wizerunkiem i materialnymi śladami jego obecności. Aby nie prowokować wrażliwości i potęgi uczuć religijnych w naszym kraju, wielokrotnie podkreślano, że prezentacja ta nie jest krytyką postaci papieża, jego nauk, a jedynie niektórych cech jego kultu (Koehler, 2014, ss. 18-19). Zgodnie z koncepcją swojego artykułu przywołam jedną z prezentowanych na tej wystawie prac: fotografię Zofii Rydet ${ }^{9}$ zatytułowaną „Obecność” (fotografia, 1982-1984, Fundacja Zofii Rydet). Praca

9 Zofia Rydet (1911-1997) to jedna z najwybitniejszych postaci fotografii polskiej. Jest autorką słynnych cykli fotograficznych zatytułowanych "Mały człowiek” i „Czas przemijania” oraz „Zapisu socjologicznego Anno 1978-1990 (suwalskie, lubelskie, kieleckie, rzeszowskie, Śląsk, Spisz, Orawa, Podhale, Chochołów, PodhaleNaprawa, Kraków, Gliwice)". 


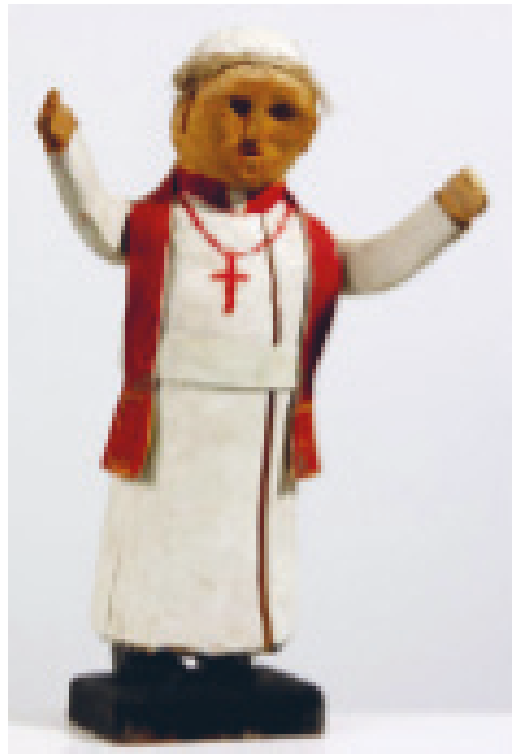

Ryc. 15. Ojciec Święty Jan Pawet II, Stanisław Hołda, 1979 r., drewno polichromowane, fot. Marian Kosicki, MET

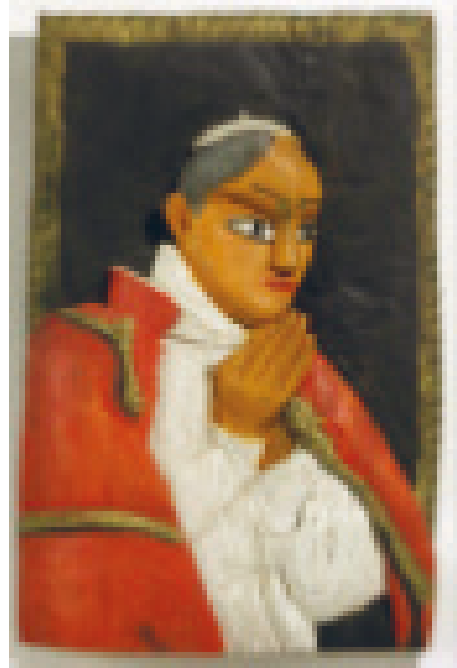

Ryc. 17. Jan Pawet II, Józef Serwik, 1984 r., drewno polichromowane, fot. Marian Kosicki, MET

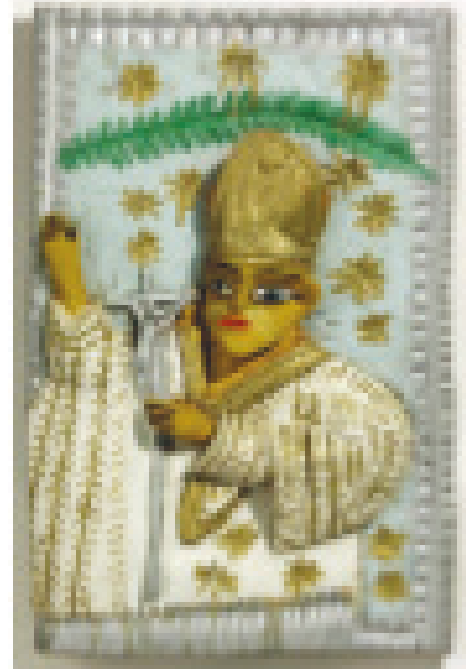

Ryc. 16. Jan Pawet II, Józef Serwik, 1981 r., drewno polichromowane, fot. Marian Kosicki, MET

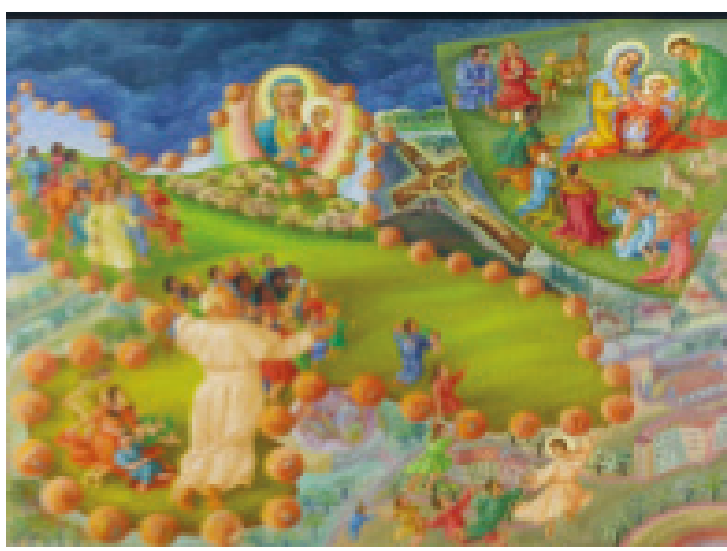

Ryc. 18. Mój Różaniec, Zofia M. Dembińska, 2000 r., olej, płótno, fot. Marian Kosicki, MET 
artystki ujęła mnie swoją subtelną aurą, z której wyłania się czysty przekaz wskazujący na główną bohaterkę - starszą kobietę, która trzyma w dłoniach fotografię przedstawiającą papieża. Autorce udało się uchwycić symboliczny w swej wymowie akt niezłomnej wiary, prostolinijne i szczere uwielbienie postaci Jana Pawła II, co warto podkreślić - pozbawione fanatyzmu. Te określenia: prostolinijne, szczere, można odnieść do rzeźb artystów nieprofesjonalnych, którzy w drewnie, z pietyzmem stawiają pomniki uwielbianej i nieskalanej postaci Jana Pawła II. Te przedstawienia niezwykle jednorodne, pozbawione dodatkowej ornamentyki, przyjmują formę pomników ku czci papieża Polaka. Ich powstanie wynika z niezwykle szczerych intencji - są hołdem dla papieża, pozbawionym zbędnej egzaltacji i nachalnej heroizacji. Autorami rzeźb przedstawiających postać papieża Jana Pawła II, które znajdują się w zbiorach toruńskiego Muzeum Etnograficznego, są Antoni Baran, Stanisław Hołda, Jan Krajewski, Szczepan Mucha, Józef Piłat, Marianna Razik, Józef Serwik. Papież Jan Paweł II w rzeźbie przedstawiany jest najczęściej w geście pozdrowienia, błogosławieństwa lub modlitwy, w biało-czerwonych szatach. Zarówno kolorystyka stroju, jak i często występujący w tytułach prac zwrot Papież Polak ma na celu podkreślenie silnej więzi głowy Kościoła z polskim narodem. Jan Paweł II, na długo przed oficjalną kanonizacją, w świadomości wielu Polaków wstąpił w poczet błogosławionych i świętych, których przedstawienia inspirowały artystów naiwnych. Nadmienię, iż nieodłącznym elementem pielgrzymek papieża Jana Pawła II do ojczyzny są wystawy sztuki ludowej oraz udział artystów w dekoracji ołtarzy. Podczas pielgrzymki Ojca Świętego w 1999 roku rzeźbiarze ludowi wykonali fragment ottarza papieskiego na sopockim hipodromie. Udział w tych przedsięwzięciach twórcy traktują jako swój patriotyczny obowiązek i czynnik nobilitujący. Postać Papieża Polaka nie tylko fascynuje, ale przede wszystkim budzi dumę i patriotyczne uczucia związane z przynależnością do tego samego narodu.

\section{SZTUKA WSPÓLCZESNA A SZTUKA NIEPROFESJONALNA}

Czułość percepcji i głębia spojrzenia artystów nieprofesjonalnych decyduje o swoistej estetyzacji historii. Sztuka nieprofesjonalna, w przeciwieństwie do współczesnej sztuki krytycznej, nie chroni przed dogmatyzmem i nie burzy mitów narodowych. Ma ona w sobie coś z przedstawień teatralnych, w których występują tylko najwspanialsi aktorzy w swoich życiowych rolach. W przypadku twórców nieprofesjonalnych można zauważyć odejście od kultu przedmiotu - wytworu autora na rzecz kultu postaci. Splendor dzieła, jego piękno wynika z tematu. Kwestia sławy autora to rzecz drugorzędna lub wręcz nieistniejąca w świadomości twórcy nieprofesjonalnego. Historyczna wizja jest podporządkowana bohaterom, czynom, które zasłużyły na upamiętnienie. To oni są wielcy, nie autor. Postaci historyczne przez nich uwiecznione to często odlewy posągowych herosów, którzy niczym mityczni bohaterowie zastygają w formie niezmiennej, ostatecznej - tak jak mamy ją widzieć, pamiętać, myśleć o niej. Tematyka martyrologiczna jednoznacznie wskazuje kierunek odbioru dzieła. Nie ma szokować, wprowadzać ferment w umyśle odbiorcy. Jej przekaz jest precyzyjny - ma upamiętniać to, co podsycane jest takimi emocjami jak smutek, strach, współczucie, żal, podziw i szacunek. W obydwu przypadkach zarówno w sztuce współczesnej jak i nieprofesjonalnej ich odbiorca poszukuje „ikon tożsamości", chcąc dowiedzieć się - kim jest oraz gdzie się znajduje (Belting, 2011, s. 9). Mimo iż sztuka współczesna sprzyja wyrażaniu osobistej wolności, rezygnując z przedsta- 
wienia oficjalnej historii, tak samo jak w twórczości intuicyjnej ma na celu chronić nasze doświadczenia. W obydwu przypadkach można wskazać na cechę uniwersalną - sztuka jest w stanie uchwycić i w skrócie utrwalić wydarzenie, o którym napisano już wiele tomów naukowych rozpraw.

W przekazach ikonograficznych twórców nieprofesjonalnych miejsce szczególne zajmuje zespół tematyczny, który możemy nazwać swoistym pomnikiem kultywującym pamięć historyczną. Martyrologia narodu polskiego z naciskiem na wydarzenia II wojny światowej inspirowała i inspiruje twórców, pobudza ich wyobraźnię i zmusza do twórczej kreacji. Stąd też zarówno w rzeźbie w drewnie, ceramice, na obrazach, w malarstwie na szkle na przykładzie zbiorów sztuki toruńskiego Muzeum Etnograficznego możemy odnaleźć bogatą reprezentację „pomników sztuki patriotyzmu”.

\section{BIBLIOGRAFIA}

44. Antologia komiksu o Powstaniu Warszawskim. (2007). Warszawa: Wydawnictwo Muzeum Powstania Warszawskiego.

Belting, H. (2011). Historia w sztuce wystawiona na próbę. (J. Burzyński, Tłum.). W M.A. Potocka (Red.), Historia w sztuce. Katalog wystawy. Kraków: Muzeum Sztuki Współczesnej w Krakowie.

Bernatowicz, P. (2009). Nie robię nudnych rzeźb. Rozmowa z Davidem Černym. Arteon, 106(2).

Bourriaud, N. (2011). Anioł Mas. Wykorzystanie ruin i strzępków historii w sztuce współczesnej. (Ł. Białkowski, Tłum.). W M.A. Potocka (Red.), Historia w sztuce. Katalog wystawy. Kraków: Muzeum Sztuki Współczesnej w Krakowie.

Domańska, E. (2011). Sztuka jako przyszłość historii. W M.A. Potocka (Red.), Historia w sztuce. Katalog wystawy. Kraków: Muzeum Sztuki Współczesnej w Krakowie.

Gajdziszewska, B. (2008). Wujkowski artysta. Pobrano 16 grudnia 2015, z http://www. sgie.pl/nr_14_(1019)_4_kwietnia_2008_-_wujkowski_artysta,490.html

Jasiński, M., Michalski, J., \& Janicki, A. (2006). 1981. Kopalnia Wujek. Poznań: Zin Zin Press.

Jasiński, M., Michalski, J., Tkaczyk, W., \& Żwikiewicz, W. (2006). 1956 - Poznański Czerwiec. Poznań: Zin Zin Press.

Koehler, O. (2014). Krótki a smutny wykład z ironii. Arteon, 173(9).

Pokropek, M. (2009). Pamięć o wojnie. Wystawa sztuki dla upamiętnienia 70. rocznicy wybuchu II wojny światowej 1-17 września 1939 r. Katalog wystawy 2009-2011. Otrębusy: Muzeum Sztuki Ludowej w Otrębusach.

Pomian, K. (2006). Historia - nauka wobec pamięci. (H. Abramowicz, Tłum.). Warszawa: Wydawnictwo Uniwersytetu Warszawskiego.

Poprzęcka, M. (1998). O złej sztuce. Warszawa: Wydawnictwo Artystyczne i Filmowe.

Potocka, M. A. (2011). Sztuka i historia. Historia w sztuce. Katalog wystawy. Kraków: Muzeum Sztuki Współczesnej w Krakowie.

Pyka, H. (2008). Franciszek Kurzeja z głębi - śląska sztuka nieprofesjonalna. Katalog do wystawy. Katowice: Wydawnictwo Fundacja dla Śląska. 